\section{Factors Affecting the Shortage and or Provision of Sustainable Affordable Housing in Developing Countries - A Case-Study of Cross River State, Nigeria}

\section{Aniebietabasi Ackley*, Catherine Teeling}

Portsmouth School of Architecture, University of Portsmouth, United Kingdom

\section{Eugene Atamewan}

Department of Architecture, Cross River University of Technology, Calabar, Nigeria

${ }^{*}$ Corresponding author: Aniebietabasi.Ackley1@myport.ac.uk

$\Gamma$ crossef $h t t p: / / d x . d o i . o r g / 10.5755 /$ j01.sace.22.1.20573

The problem of shelter in developing countries is the shortage of affordable housing especially for the urban poor. This housing shortage exposes the citizens to live in inadequate housing conditions. This study presents evidence of the factors affecting the shortage and or provision of sustainable affordable housing in Cross River State, Nigeria. Primary data was collected from semi-structured interviews and unobtrusive observations. This data was then analysed using descriptive statistics (frequency counts and simple percentages). The study findings revealed that, many interviewees suggested that rural-urban migration $98 \%(n=48)$, and lack of planning, maintenance and management $90 \%(n=45)$ as the main factors leading to the shortage of affordable housing. The interviewees suggested that poor implementation of government housing policies $84 \%(n=42)$, difficulty in purchasing land $94 \%$ ( $n=47)$, the high cost of building materials $96 \%(n=48)$, and lack of finance and access to credit facilities $80 \%(n=40)$ were significant challenges hindering the provision of sustainable affordable housing. The study concludes that affordable housing shortage and or provision can be minimised and enhanced by encouraging building developments that are; flexible and smart with minimal usage of non-renewable energy, use of durable and locally available building materials that respond appropriately to environmental factors and forces, availability of housing for the target population and a switch to a more sustainable way of planning, design, construction and maintenance of buildings.

Keywords: Sustainable, affordable housing, Cross River State, Nigeria.

The UN Habitat agenda, (2005) describes affordable housing as an important component to establish sustainable development for both society and the economy. It states that a functioning housing sector that offers appropriate affordable housing along with a sustainable pattern of urbanisation is critical for the future of any country. Housing is a fundamental necessity for every human being, irrespective of financial standing. American psychologist, Abraham Maslow ranked shelter as second only to food in his hierarchy of human needs and this is generally accepted. Despite the importance of housing to the socioeconomic development of man and society as a whole, housing problems have remained endemic throughout the world (Otubu, 2012).

The term 'Housing Conditions' is defined as the total state of the physical environment and the
JSACE $1 / 22$

Factors Affecting the Shortage and or Provision of Sustainable Affordable Housing in Developing Countries - A CaseStudy of Cross River State, Nigeria

Received 2018/04/23

Accepted after revision 2018/07/05

\section{Introduction}

\section{ktu}

Journal of Sustainable Architecture and Civil Engineering Vol. 1 / No. 22 / 2018 pp. 27-38

DOI 10.5755/j01.sace.22.1.20573 (C) Kaunas University of Technology 
satisfaction level of a particular dwelling unit measured against variables that makes it liveable at a particular time (Omole, 2001). The variables relating to housing conditions include safety, security, structural stability, environmental quality, light, heating, ventilation; as well as basic infrastructure services such as water, sanitation and waste disposal facilities (UN-Habitat, 2005). The sustained quality of better housing conditions in any area is a function of the characteristics of the various materials that make up the building, the spatial quality, response to site conditions and other socio-economic factors that affect the environment (UN-Habitat, 2005; Akpan-idiok \& Ackley, 2017).

The provision of affordable housing has always been a significant problem in Nigeria that requires addressing. Mundra and Sharma, (2014) suggested that, millions of people especially the low-income earners are still living in inadequate housing in many countries most particularly in developing countries. Cross River State today is such an example, it has a significant lack of and problem of affordable housing provision for its ever increasing (Urban) population/citizenry (Ewa, Offiong, Njar, \& Ita, 2013).

The increase in urban population have made housing difficulties more serious for lower income groups and the problem has been complicated by inflated real estate values, speculative activity, unemployment, low earning capacity and lack of maintenance and planning (Otubu, 2012). The housing problems in Cross River State have led to social, cultural, psychological, and environmental problems for the citizens. It has resulted in low standards of living, and the growth of slum neighbourhoods that have become common features of the state's urban areas (Ewa, et al, 2013). Therefore, the challenges affecting the shortage and the provision of affordable housing relies on addressing issues specific to many of the slum settlements.

\section{Literature Review}

\section{Housing Situation and Overview of Housing Schemes in Nigeria}

The Housing situation in Nigeria has been affected by the increase of significant rural-urban drift. This has been influenced (or caused) by the lack of development of the rural areas, the government bias in the choice of location for urban public infrastructure, and the poor economic conditions of the rural dwellers (Olotuah \& Ajenifujah, 2009).

A brief review of past housing policies and programmes in Nigeria highlights the different periods of official intervention in housing delivery. These include; the colonial period, post-independence period, post Second Republic periods and the current housing programmes.

\section{The Colonial period (1928- 1960)}

The National Housing Policy (NHP, 1991) states that, due to the Bubonic Plague epidemic between 1928- 1929 the then government of the defunct Lagos Colony brought into existence by law the Lagos Executive Development Board (LEDB), which was charged with the responsibility of planning the development of the capital city of Lagos. This led to the production of a masterplan for the layout of Ebute Metta area of Lagos.

This housing scheme was developed specifically to house civil servants and was executed through a payroll deduction system. In 1955, during the preparation for independence, the concern for slum conditions became paramount and subsequently brought the central Lagos slum clearance scheme into effect. The scheme opened up Apapa and later Victoria Island as high and low-density developments within Lagos State. Additionally, slum clearance programme enabled the construction of additional houses in Surulere area of Lagos State, this was the first attempt in urban renewal in Nigeria (NHP, 1991).

The aim of the slum clearance scheme was partly designed to provide temporary residential housing for displaced people from the slum areas of central Lagos, providing the re-allocation of redeveloped land in central Lagos, this however became permanent housing for the previous 
slum dwellers. The actions by the Lagos Executive Development Board (L.E.D.B.) produced many solutions such as; the Eric Moore and Akinsemoyin housing estate, Surulere, phase II of the workers housing estate and Surulere, Lupe and Isolo estates among others (Jiboye,2011).

In 1958, the Western Regional Government pioneered the establishment of housing corporations, which was replicated by other regions of Nigeria. The main function of the housing corporations was the construction of housing units for sale to members of the public, this was achieved through the provision of loans to whoever wished to build their own house on their land (Jiboye, 2011). Most of these estates are currently deteriorating due to lack of maintenance and management.

\section{Post-independence period (1960-1983)}

During this period many initiatives were established in the Eastern, Western and Northern Regions that explored the potential of housing corporations, followed by a National Council of Housing that enabled mortgage repayment schemes. This scheme allowed people to borrow money to build houses that could be repaid over many years. The schemes failed because they only focused on developments in capital cities, which were left to deteriorate. With public production of shelter as a priority, the period of 1971-1980 had a significant level of increase in the supply of housing due to government participation. This were because of the interest and involvement of the public sector in shelter delivery and its importance within the overall economy.

With the establishment of the Federal Housing Authority (FHA) in 1976, the National Housing Programme was launched. This program provided affordable housing to Nigerian citizens on longterm mortgage repayment terms and it is viewed as the first significant effort of the Nigerian government to provide affordable housing in Nigeria. It led to the development of Festival Town and lpaja Town in Lagos, the Amuwo Odofin Phase 1 Estate in Lagos and the first ever federal lowcost housing estates in a further 11 state capitals of Nigeria. FHA was established under Decree No. 40 of 1973 and amended by CAP 136 LFN of 1990.

In 1979, the Nigerian government embarked upon low cost housing development in all of the 19 states of the country, the government allocated N1.9 billion for housing construction, in all the twenty states of Nigeria, including Abuja. By June 1983, N600 million (37.5\%) had been spent to complete only 32,000 units, yielding an overall achievement level of just 20 per cent (Jiboye, 2011). This period witnessed the continued increasing deficit on urban housing as well as its continuous deterioration in the rural areas.

\section{Post Second Republic periods (1984 to 1999)}

During this period, Nigeria was faced with the challenges of having many suspended/abandoned housing projects due to the failure of previous housing programmes. Thus, the completion of the abandoned housing stock became the focus of the government (Thisdayonline, 2009). To complement the above, the government in 1994-1995 launched the National Housing Programme designed to provide about 121, 000 housing units to all income groups in Nigeria (Lanrewaju, 2013). The program was focused on establishing a permanent housing delivery system that will not be solely reliant on the government treasury, but rather self-sustaining and enduring (Lanrewaju, 2013). Due to inadequate funding, planning and conception, poor implementation, lack of public confidence, problems of access to the National Housing Fund, under-pricing, costing and inflation this programme failed (Thisdayonline, 2009).

\section{Current Housing Delivery Scheme 2000- till date}

In 2003, the federal government established the Federal Ministry of Housing and Urban Development (FMHUD), and Proposed a Housing Reform. There was an illusion that houses were available. Mabogunje (2004) suggested that other legislative requirements must be amended substantially to bring their provisions in line with the new housing regime. This policy placed the private 
sector in a focal position for the delivery of sustainable affordable houses. The Ministry of housing also reviewed and amended the Land Use Act to ensure efficient access and facilitated land registration process, along with a new mortgage regime to accelerate more favourable mortgage terms (Thisdayonline, 2009). The new National Housing Policy came into publication in January 2004. The framework for its operation involved restructuring of existing structures and new laws. Within this, a new Federal Ministry of Works and Housing was created from which a new national housing policy emerged, ensuring the construction of one million houses annually to boost infrastructural development (Oyekachi, 2014). This social housing policy adopted a position where every citizen 'counts' in the provision of affordable housing.

In August 2014, the Nigerian government launched the first 10,000 Affordable Housing Mortgage Scheme under the Nigerian Housing Finance Programme, in an effort to help bridge the housing deficit in the country. Studies show that the national housing deficit from1991 increased from 7million into an estimate of 12 - 15 million units in 2008 and over 16million in 2013. This represents housing for about 130-140million people, of which more than $65 \%$ represents the low and medium income groups of Nigeria population. This signifies about $85 \%$ of the housing demand for the nation (Oyekachi, 2014). This increase illustrates the inadequacies of the policies that have been adopted over the years and that the housing developments are not within the reach of the low and medium income groups. Hence, Many Scholars (Omole, 2001, Diogu, 2004, Jiboye, 2011, Otubu, 2012, Lanrewaju, 2013 and Oyekachi, 2014). have identified; Unsuccessful government programmes which lacked continuity with changes of Government, inadequate funding of most of the projects, corruption, lack of planning, maintenance and management of housing projects, poor design and implementation as reasons for the failure of many housing schemes in Nigeria: These illustrate the difficulties and drawbacks for any possible recommendations that will enhance the provision of affordable housing in Nigeria. In proffering recommendations to tackle Nigeria's housing problems, Oyekachi (2014) suggested that, a housing policy which facilitates self-help ownership at an affordable price is the best policy option that Nigeria should adopt and that, Nigeria's housing finance system needs reinforcement to enable the urban and rural citizen's easy access to credit facilities.

\section{Materials and Methods}

\section{Study Location}

The study investigated two residential housing developments in Cross River State. The first is the Federal Housing Estate Development (FHE), Calabar built in the 1980s. It was selected for analysis because it formed part of the Nigerian National Housing Policy prototype building programme for low income earners. The second housing development is Crospil housing estate located at Akpabuyo Local Government Area (LGA) of Cross River State. It is an on-going housing development built by the Cross-River State government with the first of its phases completed in 2010. Both developments are located in latitude $4.9^{\circ}$ North and Longitude $8.32^{\circ}$ East in the coastal
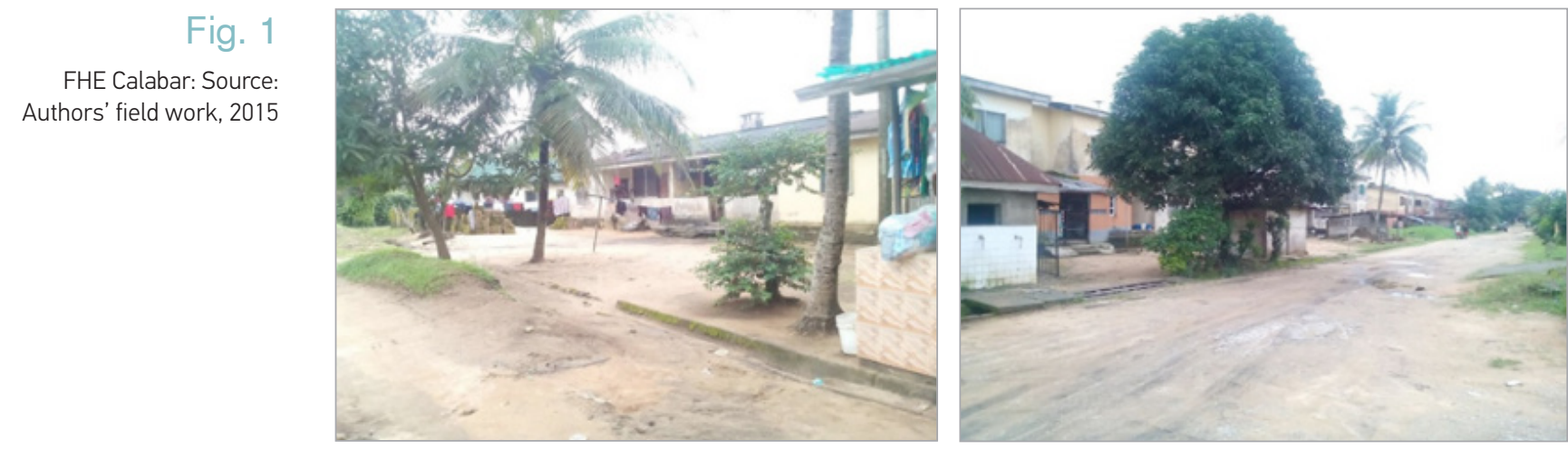

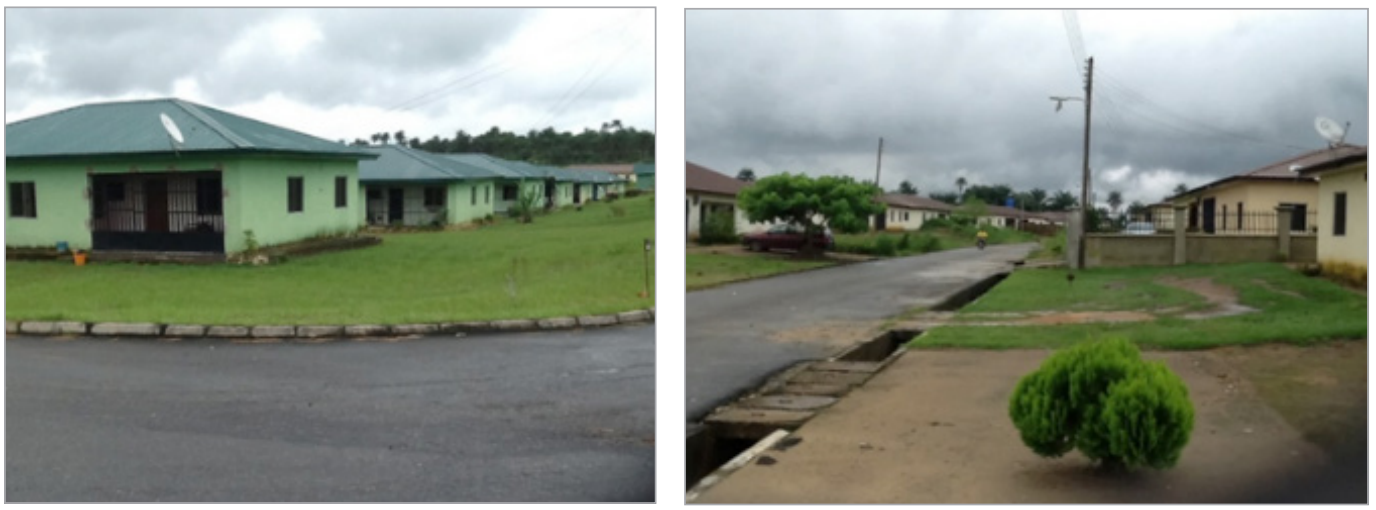

Fig. 2

Crospil Housing Estate, Akpabuyo: Source: Authors' field work, 2015
South-Eastern part of Nigeria with a distance of $13 \mathrm{~km}$ apart and $12 \mathrm{~m}$ height above sea level. Calabar and Akpabuyo are in the tropical rain forest of Nigeria; the mean temperature is about $25^{\circ} \mathrm{C}$, the annual rainfall exceeds 300 millimetres, and the relative humidity is high throughout the year (Akpan-Idiok, 2012).

\section{Study Population}

Data was collected from fifty tenants overall. This housing was designed for government employees. Thirty tenants were interviewed in Calabar and 20 were interviewed at Akpabuyo.

\section{Sample and Sampling Technique}

Fifty housing units were randomly selected for the interviews, using a systematic sampling technique of about $10 \%$ of total units in each housing estate. The interviews were conducted over a period of three weeks in early 2015. The number for the selection was based on the time limitations. Calabar FHE has around 300 housing units which include, two and three-bedroom two storey buildings, two and three-bedroom bungalows as well as one-bedroom bungalows. Most of the buildings in the estate have recently been demolished due to the un-repairable state of the buildings and new private structures are currently being erected. Akpabuyo Crospil estate has 200 housing units consisting of 64 three bedrooms detached two storey dwellings and 98 three-bedroom semi-detached bungalows; 26 two-bedroom semi-detached bungalows as well as 12 units of one-bedroom two storey terraced housing.

\begin{tabular}{l|c|c|c|c|c}
\hline Location & $\begin{array}{c}\text { Total Number of } \\
\text { House types }\end{array}$ & $\begin{array}{c}\text { Number of } \\
\text { estates selected }\end{array}$ & $\begin{array}{c}\text { Total number of } \\
\text { housing units in } \\
\text { the estates }\end{array}$ & $\begin{array}{c}\text { No of selected hous- } \\
\text { ing units/households } \\
(10 \% \text { of total) }\end{array}$ & $\begin{array}{c}\text { Interviews } \\
\text { undertaken }\end{array}$ \\
\hline Calabar & 3 & 1 & 300 & 30 & 30 \\
\hline Akpabuyo & 4 & 1 & 200 & 20 & 20 \\
\hline
\end{tabular}

\section{Ethical Considerations}

A letter of introduction and permission was taken to the community leaders in order to gain access to carry out the study. Verbal consent was also obtained from the interviewees before the study commenced.

\section{Instrument for Data Collection}

Data for this research was obtained through a semi structured face to face interview. This method allowed each interviewee to express their perspective of how their houses function as well as the problems with the form of affordable housing and their environment. The unobtrusive observation method was also

\section{Table 1}

Housing Samples for interview: source: Authors' field work, 2015 


\section{Results}

\section{Table 2}

Socio-demographic data of interviewee: Source: Authors' field work, 2015 used to gather data. This allowed the authors to record the respondent's behaviour within the houses with specific end goals to assess how the house was used and quality of the living conditions. This method was used because the authors were familiar with the environment of both case studies, the form and mode of construction of the houses, attitude and manners which the people exhibit, and the ways the individuals viewed things. The data obtained were analysed using descriptive statistics such as percentages.

\section{The Socio-demographic data of interviewee $(n=50)$}

Fifty interviewees participated in the study, many of the interviewees were females $80 \%(n=40)$ and married 70\% ( $n=35), 80 \%(n=40)$ were Christians and 60\% (n-30) between the ages of 35 to 49

\begin{tabular}{|c|c|c|c|}
\hline $\mathrm{S} / \mathrm{N}$ & Item & Num & Percentage (\%) \\
\hline 1. & \multicolumn{3}{|c|}{ Sex } \\
\hline & Male & 10 & 20 \\
\hline & Female & 40 & 80 \\
\hline \multirow[t]{5}{*}{2.} & \multicolumn{3}{|c|}{ Age } \\
\hline & $20-34$ & 3 & 6 \\
\hline & $35-49$ & 30 & 60 \\
\hline & $50-64$ & 15 & 30 \\
\hline & 65 and Above & 2 & 4 \\
\hline \multirow[t]{5}{*}{3.} & \multicolumn{3}{|c|}{ Religion } \\
\hline & Christianity & 40 & 80 \\
\hline & Islam & 1 & 2 \\
\hline & Eckist & 5 & 10 \\
\hline & Others & 4 & 8 \\
\hline \multirow[t]{6}{*}{4.} & \multicolumn{3}{|c|}{ Marital Status } \\
\hline & Single & 1 & 2 \\
\hline & Married & 35 & 70 \\
\hline & Divorced & 9 & 18 \\
\hline & Widow & 4 & 8 \\
\hline & Widower & 1 & 2 \\
\hline \multirow[t]{5}{*}{5.} & \multicolumn{3}{|c|}{ Occupation } \\
\hline & Farmer & 1 & 2 \\
\hline & House Wife & 3 & 6 \\
\hline & Trader & 6 & 12 \\
\hline & Civil Servant & 40 & 80 \\
\hline \multirow[t]{5}{*}{6.} & \multicolumn{3}{|c|}{ Level of Monthly Income } \\
\hline & N20,000 - N39,000 & 5 & 10 \\
\hline & N40,000 - N59,000 & 10 & 20 \\
\hline & N60,000 - N89,000 & 30 & 60 \\
\hline & N90,000 and Above & 5 & 10 \\
\hline \multirow[t]{4}{*}{7.} & \multicolumn{3}{|c|}{ Nationality } \\
\hline & Nigerian & 50 & 100 \\
\hline & Foreigner & 0 & 0 \\
\hline & & 50 & 100 \\
\hline
\end{tabular}


years. Majority of interviewees were civil servants $80 \%(n=40)$ with $60 \%(n=30)$ having an average monthly minimum income of N60, 000 Naira ( $£ 250)$, and all were Nigerians, 100\% ( $n=50)$.

All interviewees were permanent residents with majority having at least more than two years' occupancy within their apartments and houses.

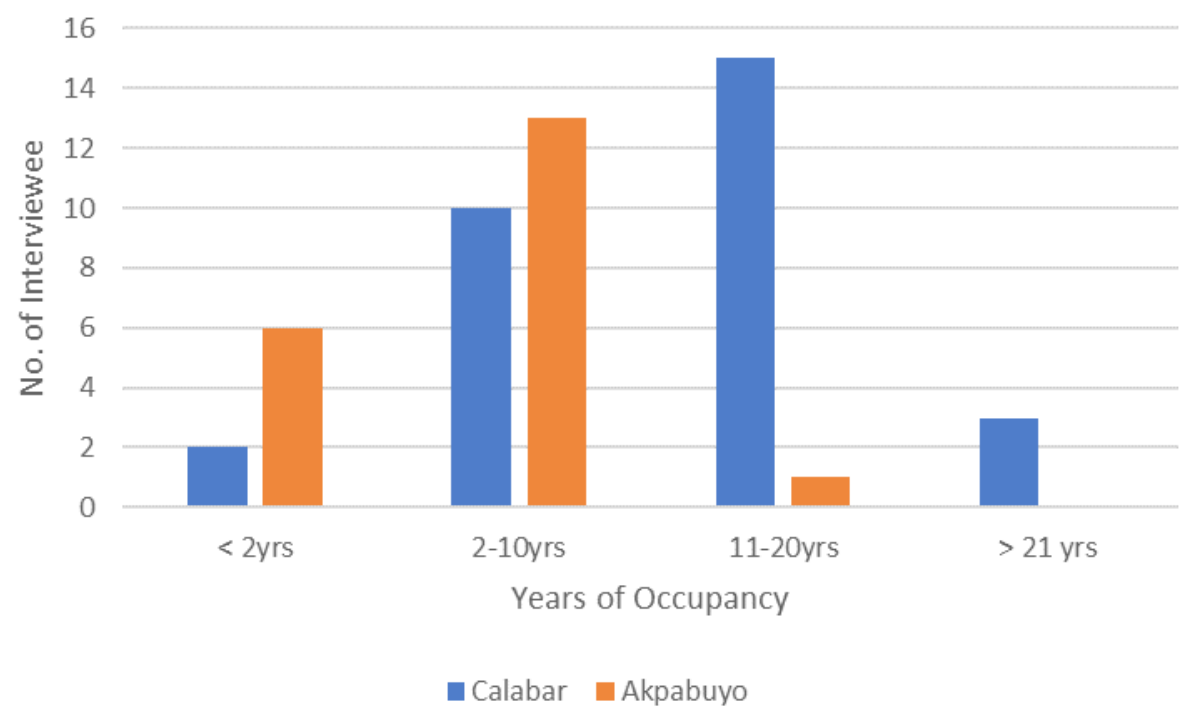

\section{Factors Affecting the Shortage and Provision of Affordable Housing in Cross River State}

As shown in table 3 below, high rural-urban migration, $96 \%(n=48)$, High cost of building materials $96 \%(n=48)$, difficulty in purchasing a land $90 \%(n=45)$, poor maintenance of existing buildings $90 \%$ $(n=45)$, and poor implementation of government policies $42 \%(n=84)$ are key among the various

\begin{tabular}{l|l|l}
\hline \multicolumn{1}{c|}{ Factors } & $\mathrm{n}-50$ & $\%$ \\
\hline High rate of Rural-Urban Migration & 48 & 96 \\
\hline Poor planning and maintenance of existing buildings & 45 & 90 \\
\hline Poverty (Inadequate Finance) & 40 & 80 \\
\hline Use of inferior building materials & 43 & 86 \\
\hline Poor basic infrastructure provision by government & 34 & 68 \\
\hline Poor implementation of government housing policies & 42 & 84 \\
\hline High cost of rent & 37 & 74 \\
\hline Destruction of facilities by occupants & 30 & 60 \\
\hline Poor design and implementation & 39 & 78 \\
\hline Environmental problems (Pollution, flooding, topography) & 40 & 80 \\
\hline Difficulty in purchasing land for building & 47 & 94 \\
\hline High cost of building materials & 48 & 96 \\
\hline Difficulty to access credit facilities & 40 & 80 \\
\hline High cost of maintenance & 38 & 76 \\
\hline High risk of fire incidents & 26 & 52 \\
\hline High cost of labour to build & 35 & 70 \\
\hline Abandoned government housing projects & 35 & 70 \\
\hline
\end{tabular}

Fig. 3

Interviewees length of occupancy: Source: Author's field work, 2015

\section{Table 3}

Factors affecting the shortage and provision of affordable housing: Source: Author's field work, 2015 
factors affecting the shortage and provision of affordable housing. The table below presents a list drawn up from the responses to the interview and questions.

When interviewees were asked if their house is suitable for their status, 90\% $(n=45)$ of interviewee said no, because of most of the factors stated above. When interviewees where asked of what improvements they would recommend for the provision of affordable housing, a large majority of interviewees recommended a positive improvement to the different challenges mentioned in table 3 above, such as: provision of basic amenities (light and water, etc); the use of good building materials that have longevity; and access to credit facilities to assist the building of their houses with a low or possibly no interest rate.

Discussion

It is evident from the study that, majority of interviewees identified high rural-urban migration as a major factor contributing to the shortage of affordable housing in Cross River State. High population growth drifts constantly to urban areas, with corresponding inadequate measures for the provision of affordable housing for the populace gives rise to slum and squatter housing; an offshoot of overcrowding which results in high building density and high occupancy rate. The large population of people in the urban cities of Cross River State is a challenge to the accessibility of affordable housing in its urban cities. The statistic in Fig. 1, 2 and 3 below showed the progressive increase in the population of Nigeria up to 2015.

The bar chart above shows the changes in population as a result of people migrating into the urban cities of Nigeria. Migration is said to occur both on a short term or long-term basis depending on the conditions in which people find themselves in. As a result, the proportion of the Nigerian population living in urban centres has increased phenomenally over the years. Over $50 \%$ of Nigerians as indicated in the chart above now live in urban centres. This has created severe housing problems, resulting in overcrowding, shortage of housing and a situation in which about $60 \%$ of Nigerians can be said to be 'houseless persons'.

Majority of interviewees acknowledged that, poor planning and maintenance of existing buildings contributes significantly to the shortage of affordable housing. For a structure to remain durable, it is important that there is a good maintenance policy in place. Where buildings are not maintained and they have been allowed to deplete for a very long time, the rehabilitation and renovation becomes costly, capital intensive and sometimes properties are abandoned rendering them unusable and depleting the existing housing stock. Similarly, it was observed that most occupants also destroy their houses and associated facilities to a condition where they become inhabitable

Nigeria's Population Statistics: Source: Worldometers.info, 2015

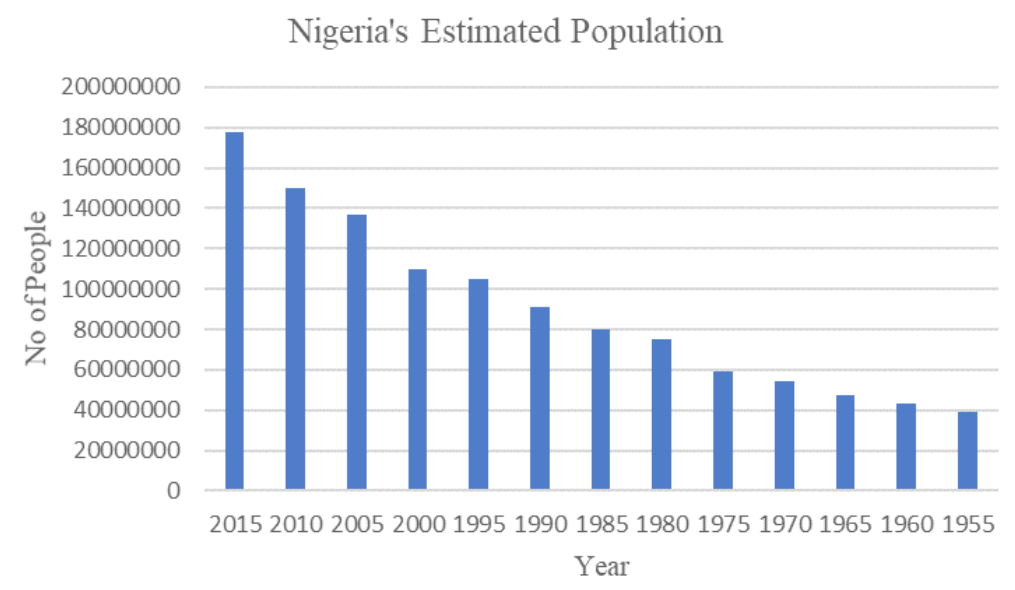



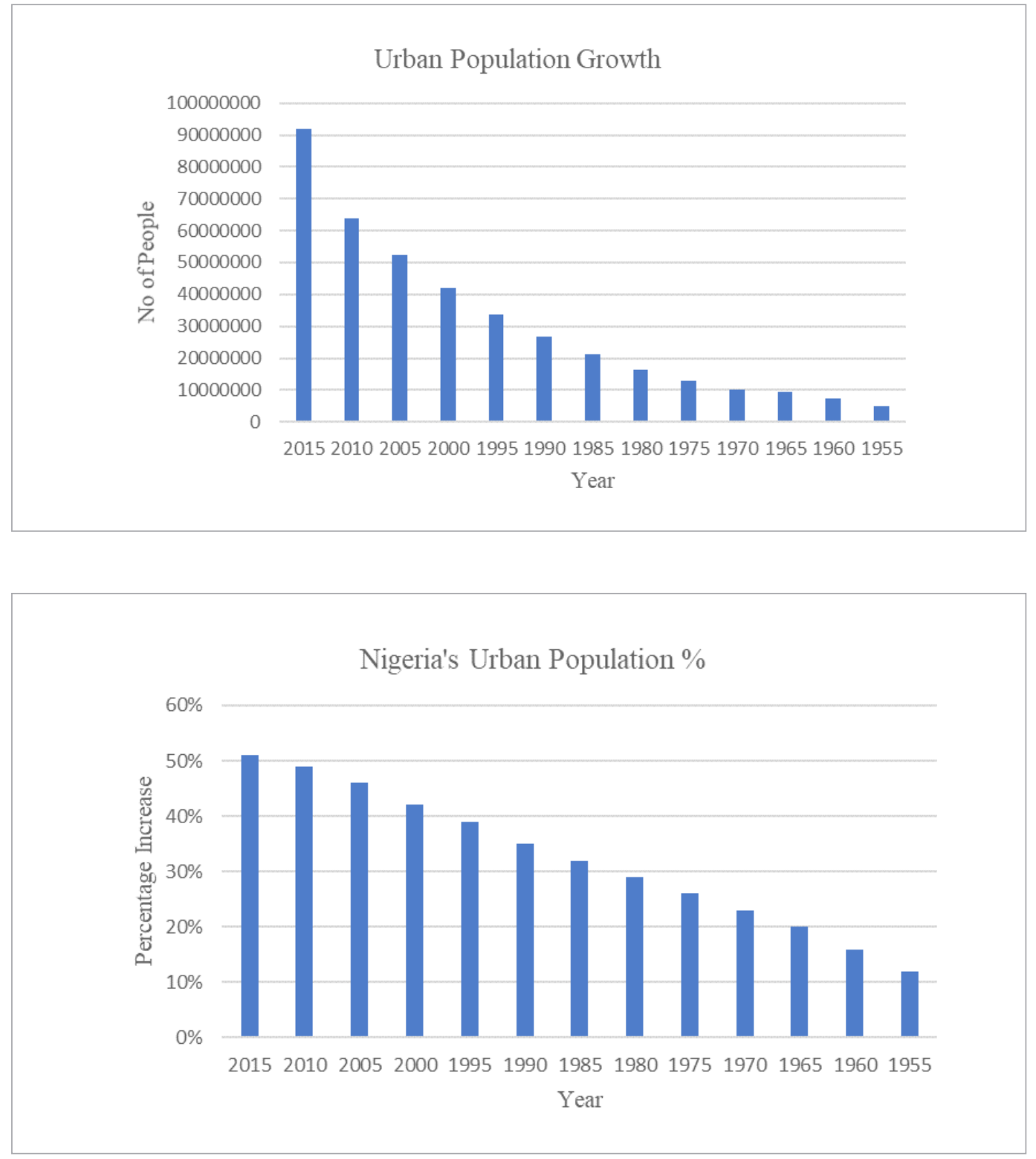

and are eventually abandoned. In some cases, houses are subject to high risk of fire incidents in Nigeria, thus houses are engulfed by fire and left abandoned. These buildings are not rehabilitated either by individuals or the government and over a long period of time the properties completely deteriorates decay and are destroyed.

The use of inferior building materials was identified by $86 \%$ of interviewees as a factor resulting in the shortage of affordable housing. Buildings rapidly decay because of the use of poor quality (inferior) building materials in the construction, this largely impacts on the life expectancy of the existing housing stock and the long-term durability of the buildings. This depletes existing housing within a few years, thereby not meeting any aim towards sustainability, and clearly not addressing the needs of the present generation as well as that of future generations. Furthermore, high rental costs were identified as another significant factor with many interviewees commenting that, people living in government low cost housing estates are mostly middle-income earners. This because government housing programmes in terms of building design do not respond to the

\section{Fig. 3}

Population changes in Nigerian urban areas: Source: Worldometers. info, 2015

Fig. 4

Percentage changes in Nigerian urban areas: Source: Worldometers. info, 2015 
target of the low-income population in the long term, and has resulted in middle and high-income earners who have the finances to highjack the completed developments.

When asked the challenges of providing affordable housing by building their own houses; interviewees identified difficulty in purchasing land to build, lack of finance, access to credit facilities, lack of insurance policies to share risk, high cost of labour to build and high cost of building materials as a major drawback to providing, building and owning a house. The Nigerian Land Use Act of 1978 vests all land in the government making this an obstacle to land available for housing development. Unfortunately, in Nigeria there is no mechanism for risk sharing and insurance policies that will encourage banks and other financial institutions to extend mortgage loans to people at the lower income level. Nigerian financial institutions settle for lending to the rich. There is also absence of a National credit database that can provide credit information of all individuals that enjoy financial services in any form. With the Nigerian building industry largely dependent on imported foreign building materials and considering the current economic crises of the country resulting in high exchange rates; there is a drastic rise in the cost of building materials. These factors have significantly hindered the provision of affordable housing.

About $80 \%$ of interviewee said that the government is responsible for the challenges facing the provision and shortage of affordable housing. Inadequate provision of basic infrastructure by government, corruption, poor implementation of housing polices and economic meltdown were identified as key reasons why government should be held responsible. It is worthy to mention that, over the years, the Nigerian and Cross River State government have enacted various housing policies and programmes aimed at providing affordable housing. These programmes have been unsuccessful because of corruption; a situation where contractors divert and embezzle money meant to execute a project and leave it abandoned. Most housing programmes lacked continuity with changes of government, and inadequate funding of most of the projects have all led to the shortage and or provision of affordable housing. The interviewee recommended the provision of basic infrastructure, and the use of sustainable local building materials as the improvements they will appreciate in providing affordable housing.

This study recommends that, to provide affordable housing in Cross River State, cheaper, durable and locally available building materials should be encouraged. This will help to reduce cost of construction which is advantageous for the provision of low cost housing. The use of environmentally degradable construction materials such as earth, thatch and turf and the application of traditional and vernacular methods which are in accordance with the traditional use of these materials. The "mud" walls of traditional buildings are similar to earth walls and adobe walls, which are enjoying as acclaim in the current trend of sustainable architecture. When used well, the clay can be aesthetically pleasing as part of a building edifice. High technology solutions such as the use of modern technology and materials that protects and conserves energy, recycling of waste materials in buildings and the production of intelligent buildings that respond appropriately to environmental factors and forces should also be encouraged.

They should be a procedure of monitoring housing schemes by the government involving all stakeholders within the community and the building industry. Integration of community engagement and participation in the development of the designs and their implementation to ensure that they meet the housing needs of the target population. To make a significant improvement in the provision of affordable houses, there is need for an enabling land use policy/law. Laws making it mandatory that houses built for the low-income group should be occupied strictly by that group. Careful policy formulation and planning in terms of the character, structure, location of the neighbourhood for affordable housing is required to ensure the appropriate performance of the corporate estate developer. Government should provide basic infrastructure in different areas and regions and create employment to discourage Rural-Urban migration. Government should 
enact and enforce policies that should do with maintaining high sanitary conditions, management of existing housing facilities and its maintenance. This should be something that must be actively maintained and at times restored. Housing construction should be monitored to ensure the use of standard building materials and techniques.

The use of renewable energy strategies (Solar panels, wind turbines, wave and tidal power) to resolve the issues of power shortage is a sustainable strategy for the provision of a sustainable affordable housing. Architects and planners should be encouraged to provide eco-friendlier designs integrating every sector of living, including the implementation of smart growth initiatives thereby providing a frame work for future development. Moreso, the citizens should be educated on loan facilities and public-private partnership in development should be encouraged. Finally, adequate planning should be done by the planning authorities in Cross River State to provide a mechanism to balance environmental and economic factors, by providing a framework to integrate diverse natural resources and growth management activities in a holistic ecosystem-based approach.

This study has identified various factors affecting the shortage and or the provision of affordable housing in Cross River State. For sustainability of affordable housing delivery, the changing needs of users must be considered to design houses for the target population which meets the income level without compromising the standards of a good housing condition. To encourage sustainable affordable housing in Cross River State is a difficult challenge, the existing basic amenities and infrastructure problems are a key concern. It is important for future developments in Cross River State to adopt a more sustainable mode of planning, design, construction and maintenance of its buildings by providing housing types that promotes the culture, lifestyle of the people and the use of locally available building materials in its construction.

Akpan-Idiok, A. Physiochemical properties, degradation rate and vulnerability potential of soils forme. International Journal of Agricultural Research, 2012, 358-366.

Akpan-idiok, P., \& Ackley, A. Sustainable Therapeutic Environment; Impacts of the Indoor Environment on Users 'Perception of Wellbeing in Public Healthcare Facilities in Calabar Municipality, Nigeria. World Journal of Pharmaceutical and Medical Research, 2017, 3(6), 27-37.

Diogu, J. The Architecture of Low-Income Housing: Evolving the Micro -Residential System. Journal of the Association of Architectural Educators in Nigeria, 2004, Vol. 3 No.2.

Ewa, E., Offiong, V., Njar, G. N., \& Ita, A. E. Assessment of housing affordability problem in Calabar Metropolis, Cross River State, Nigeria. Journal of Humanities And Social Science, 2013, 16, 23-29.

Federal Republic of Nigeria. Draft of National Urban Development Policy. Abuja: Federal Ministry of Works and Housing, Nigeria, 2004.

Jiboye David. Urbanization challenges and housing delivery in Nigeria: The need for an effective policy frame work for sustainable development. Interna- tional review of social sciences and humanity, 2011 ,
Lanrewaju F. A. Housing Delivery in Nigeria: Repackaging For Sustainable. nternational Journal of African and Asian Studies, 2013.

Mabogunje, A. Urbanization in Nigeria. London: University of London press, 1968.

Mundra, $\mathrm{K}$ and Sharma, A. Housing adequacy Gap for Minorities and Immigrants in the U.S. American Housing Survey, The Institute for the study of Labour (IZA), 2012, N0. 80, 38.

Olotuah, A. Neighborhood Quality in Residential Estates: An Analytical Appraisal of Two Estates in Akure, Nigeria. International Journal of Environmental Science, 2005, 99-105.

Otubu, T. The Missing Link in Housing Sector Reforms in Nigeria. Acta Universitatis Danubius, 2012 Vol. 4, no. 1.

Omole, F. Basic Issues in Housing Development. Ondo: Femo Bless Publications, 2001.

Oyekachi, A. Effects of Governance and Policy Reforms on Affordable Housing in Nigeria. International Journal of Innovation and Scientific Research, 2014, 413-419.

\section{Conclusion}


UN-HABITAT. Cities without slumns. Sub-regional Program for Eastern and Southern Africa. Nairobi, Kenya: UN-HABITAT, 2005.
Worldometers.info. Retrieved from Elaboration of data by United Nations. World Population Prospects: Population of Nigeria: www.worldometer.info/ world-population/Nigeria-population, 2015.

\section{About the Authors \\ ANIEBIETABASI ACKLEY \\ PhD Researcher}

Faculty of Architecture and Design, School of Architecture, Victoria University of Wellington, New Zealand

\section{Main research area}

Sustainable Architecture,

Building Performance and Indoor Environmental Quality

\section{Address}

139 Vivian Street, Te Aro Campus, Wellington

Tel. +642102850560

E-mail:

Aniebietabasi.Ackley1@myport. ac.uk

\section{CATHERINE TEELING}

Architect, Senior Lecturer

Faculty of Creative and Cultural Industries, Portsmouth School of Architecture, University of Portsmouth, United Kingdom

\section{Main research area}

Urban Regeneration and Sustainable Architecture

\section{Address}

Eldon Building, Winston Churchill Avenue, Portsmouth P01 2DJ

Tel. 02392842098

E-mail:

catherine.teeling@port.ac.uk

\section{Dr. EUGENE E. ATAMEWAN}

Architect, Lecturer, Member

Nigerian Institute of Architects, Faculty of Environmental Science, Department of Architecture, Cross River University of Technology, Calabar, Nigeria

\section{Main research area}

Housing and Sustainable Architecture

\section{Address}

Department of Architecture, CRUTECH, Calabar

Tel. +2348036602248

E-mail: geneatas@yahoo.com 